\title{
Adsorption-Desorption Properties of Ammonium Ion on Zeolite Bottom Ash in Aqueous Solution
}

\author{
Galuh Yuliani ${ }^{1}$, Widya Liswanti ${ }^{2}$, Rahmadhita Murida $^{3}$, Siska Mutiara $^{4}$, Agus Setiabudi $^{5}$ \\ $\left\{\right.$ galuh@upi.edu ${ }^{1}$ \} \\ Chemistry Department, Universitas Pendidikan Indonesia \\ Jalan Dr. Setiabudi 229 Bandung 40154, West Java, Indonesia
}

\begin{abstract}
Coal bottom ash (CBA) is potentially used as a raw material in zeolite manufactures due to its high $\mathrm{SiO}_{2}$ and $\mathrm{Al}_{2} \mathrm{O}_{3}$ contents. We report the conversion of CBA into zeolites-like material via a low-temperature method of $90^{\circ} \mathrm{C}$ for $24 \mathrm{~h}$ using $\mathrm{NaOH}$ solution. FTIR spectra confirmed characteristic zeolite peaks at $980-1170 \mathrm{~cm}^{-1}, 740.6 \mathrm{~cm}^{-}$ ${ }^{1}, 439.7 \mathrm{~cm}^{-1}, 559.3 \mathrm{~cm}^{-1}$ for $\mathrm{Si}-\mathrm{O}, \mathrm{Al}-\mathrm{O}$ and Si-O-Al absorptions, respectively. XRD results indicated the formation of sodium aluminosilicate hydrat, XRF results indicated the domination of $\mathrm{Al}_{2} \mathrm{O}_{3}$ and $\mathrm{SiO}_{2}$. BET analysis resulted in the surface area of zeolite was $60.38 \mathrm{~m} 2 / \mathrm{g}$, markedly increased from the initial surface area of CBA of $0.598 \mathrm{~m} 2 / \mathrm{g}$. The maximum adsorption capacity for ammonium ions was $85.22 \mathrm{mg} / \mathrm{g}$ and the adsorption data fitted the Freundlich isotherm model. Meanwhile, the desorption study indicated that the ammonium leached rapidly in the first $3 \mathrm{~h}$ followed by a plateau in the next $71 \mathrm{~h}$.
\end{abstract}

Keywords: Bottom Ash, Zeolite, Adsorption, Ammonium Ion

\section{Introduction}

Nutrient pollution in surface and groundwater has been considered as one of the most widespread, costly, and challenging environmental problems. Surface water contamination is usually more severe in developing countries due to intensive agriculture and less stringent discharge regulations [1]. Nitrogen compounds are one of the important nutrients essential for all organisms and ecosystem life commonly found in the form of ammonium in aqueous environments [2,3]. Ammonium is, therefore, the primary form of nitrogen pollution in municipal sewage and industrial wastewater [4]. The accumulation of ammonium can lead to eutrophication in water bodies, resulting in high growth of algae and other microorganisms, as well as in increased dissolved oxygen depletion and fish toxicity [2,5]. Therefore, the ammonium removal from wastewater is becoming crucial to overcome the contamination issues.

Worldwide, the coal industry produces several million metric tons of byproducts such as fly ash, bottom ash, boiler slag, and fuel gas desulfurization material [6]. In Indonesia, coal is becoming the major energy source providing 33\% of total domestic energy demand in 2025 compared to only $14 \%$ in 2006 . As a result, coal ash production increases significantly creating a serious problem due to the hazardous properties of the ash [7] and the potential leaching of heavy metals to natural ground surfaces [8].

Bottom ash is one kind of a solid coal-waste that has a granular particle, porous, rough surfaces, and gray in color $[9,10]$. In general, bottom ash primarily consists of silica $\left(\mathrm{SiO}_{2}\right)$ and alumina $\left(\mathrm{Al}_{2} \mathrm{O}_{3}\right)$, major material for zeolite synthesis $[11,12]$. However, the utilization of the 
bottom ash only constitutes $15 \%$ of its total generation [8]. Therefore, converting bottom ash into zeolite not only alleviates the disposal problem but also potentially turns solid waste into environmental remediation material [13].

Zeolite is a framework aluminosilicate with pore dimensions of molecular sizes generated by corner-sharing $\mathrm{Al}^{3+}$ and $\mathrm{Si}^{4+}$ oxygen tetrahedral [14]. Zeolites may potentially be utilized as an excellent ion-exchange material due to their ability to preferentially remove $\mathrm{NH}_{4}^{+}$[15]. Reportedly, the conversion of bottom ash into zeolite was carried out using the alkali hydrothermal method at high temperature and high pressure [16]. Kadja, et al. [17] reported that MFI zeolite has resulted via high temperature $\left(150^{\circ} \mathrm{C}\right)$ and low temperature $\left(90^{\circ} \mathrm{C}\right)$ methods. Chiang, et al. Reported that zeolite sodium aluminum silicate hydrate and tobermorite were obtained from bottom ash via a hydrothermal method at a temperature between 20 and $250^{\circ} \mathrm{C}$ and pressure between 0-60 bar. Zhao, et al. [14] have also synthesized NaA zeolite at $673 \mathrm{~K}$ for ammonium adsorption. The result showed the maximum adsorption capacity of $44.3 \mathrm{mg} / \mathrm{g}$ of $\mathrm{NH}_{4}{ }^{+}$. Although many reports have been found in the literature for zeolite synthesis for CBA, the process mostly involved the expensive hydrothermal method and required high temperature.

Therefore, in this study, the conversion of CBA into zeolite was carried out via a direct heating method at a low temperature at $90{ }^{\circ} \mathrm{C}$ for $24 \mathrm{~h}$ using $\mathrm{NaOH}$ alkali solution as a more simple and cheaper alternative method. The resulted zeolite was then applied as an adsorbent for ammonium ions in aqueous solution. Additionally, this study involves the desorption experiment to observe the rate of ammonium leaching from the zeolite.

\section{Material and methods}

\subsection{Material}

CBA was collected from the industry at West Java, $\mathrm{H}_{2} \mathrm{SO}_{4}$ concentrated, $\mathrm{NaOH}$, ethanol, $\mathrm{NH}_{4} \mathrm{Cl}$, distilled water, phenol, sodium nitroprusside, sodium citrate, and sodium hypochlorite were purchased from Merck.

\subsection{Conversion of bottom ash into The Zeolite}

CBA sample was first pretreated using $\mathrm{H}_{2} \mathrm{SO}_{4}$ at the ratio of 1:5 via a reflux method for $4 \mathrm{~h}$ at $180^{\circ} \mathrm{C}$ and stirred at $300 \mathrm{rpm}$. Then, the pretreated bottom ash (BA) was washed and dried at $110^{\circ} \mathrm{C}$ for 90 minutes. BA was mixed with $\mathrm{NaOH}$ solutions in various doses (1:6 and 1:8) and concentrations $(2 \mathrm{M}, 5 \mathrm{M}$, and $8 \mathrm{M})$. The mixture was stirred for $10 \mathrm{mins}$ and heated in an oven at $90^{\circ} \mathrm{C}$ for $24 \mathrm{~h}$. Then, the zeolite bottom ash (ZBA) was washed using ethanol until neutral and dried at $110^{\circ} \mathrm{C}$ for 90 minutes. The CBA, BA, and ZBA samples were then analyzed using X-Rays Fluorescence Spectroscopy (XRF) Thermo Scientific ARL 9900, FTIR-8400 Shimadzu, XRD Rigaku Miniflex 600, SEM Jeol JSM-6360LA, and BET NOVA instrument.

\subsection{Adsorption study}

A known amount of adsorbent was added to the ammonium solution with different concentrations. The $\mathrm{pH}$ solution was adjusted to between 6 to $10 \mathrm{using} \mathrm{NaOH}$ and $\mathrm{HCl}$. The mixture was shaken at $200 \mathrm{rpm}$ for 20 mins. The ZBA was separated from the solution by centrifugation. Measurement of the residual concentration of ammonium was conducted using 
the phenat method. $1 \mathrm{~mL}$ of supernatant was reacted with $1 \mathrm{~mL}$ phenol, $1 \mathrm{~mL}$ sodium nitroprusside, and 2,5 mL oxidizing solution. The solution was incubated at room temperature for $1 \mathrm{~h}$. The concentration of ammonium ions in the solution was measured using a Shimadzu UV-1700 Spectrophotometer at $637.5 \mathrm{~nm}$.

\subsection{Desorption Study}

The ZBA was dried in an oven at $105^{\circ} \mathrm{C}$ and placed in a column. Aquades with a flow rate of $3 \mathrm{~mL} / \mathrm{mins}$ was passed through the column. The concentration of ammonium ions of the water passing the column was then analyzed using a Shimadzu UV-1700 Spectrophotometer.

\section{Results and Discussion}

\subsection{Conversion of Bottom Ash Into the Zeolite}

The FTIR analysis of CBA and ZBA was provided in Figure 1. The FTIR spectra showed the absorption peaks between $\mathrm{CBA}$ and $\mathrm{ZBA}$ in various doses and concentrations of $\mathrm{NaOH}$ solution. A broad intense $\mathrm{OH}$ stretching band and a weaker $\mathrm{H}-\mathrm{O}-\mathrm{H}$ deformation band were observed at $3448.5 \mathrm{~cm}^{-1}$ and $1654 \mathrm{~cm}^{-1}$ in the ZBA indicated the presence of a hydrated zeolite due to tightly bound of water to zeolite. The influence of $\mathrm{NaOH}$ was probably caused the shifting of Si-O or Al-O absorption peak to occur at $1166.9 \mathrm{~cm}^{-1}$ to $981.7 \mathrm{~cm}^{-1}$. The shift was probably due to the formation of a new product that is associated with the dissolution of the CBA amorphous phase in a strong alkaline activation solution. The two peaks at approximately $1166.9 \mathrm{~cm}^{-1}$ and $740.6 \mathrm{~cm}^{-1}$, respectively, were due to asymmetric and symmetric Si-O, Al-O stretching vibration. The absorption peak of $\mathrm{Si}-\mathrm{O}-\mathrm{Al}$ when using dose between $\mathrm{NaOH}$ solution and BA 8: 1 dan concentration $\mathrm{NaOH}$ solution $5 \mathrm{M}$ was sharper for $\mathrm{ZBA}$ due to the formation of zeolite structure.

The XRD analysis of CBA and ZBA in various doses and the concentration of $\mathrm{NaOH}$ solution are provided in Figure 2. Severals new sharp peaks were detected but not significantly and decreased contaminant in various doses, while in various concentration new sharp peaks were detected significantly at $2 \theta$ values of $12,78^{\circ} ; 17,56^{\circ} ; 28,12^{\circ}$; dan $33,42^{\circ}$ belong to sodium aluminum silicate hydrate that involved to zeolite structure group according to the JCPDS no. $38-0329$, with the formula of $1.05 \mathrm{Na}_{2} \mathrm{O} \cdot \mathrm{Al}_{2} \mathrm{O}_{3} \cdot 3.8 \mathrm{SiO}_{2} \cdot 4.7 \mathrm{H}_{2} \mathrm{O}$. 


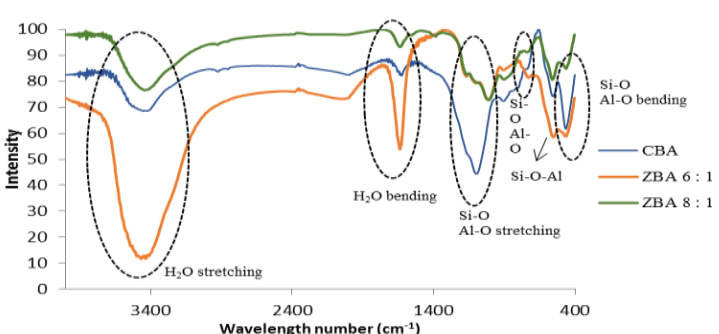

(a)

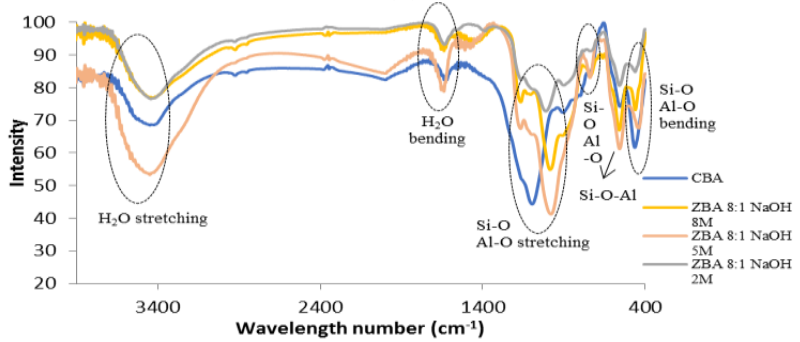

(b)

Fig. 1. FTIR spectra of CBA and ZBA in various doses (a) and concentration (b) of $\mathrm{NaOH}$ solution.

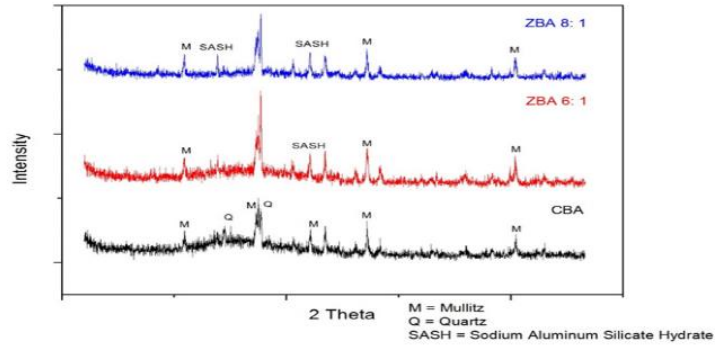

(a)

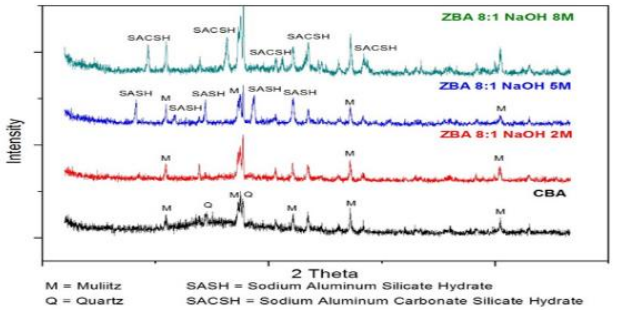

(b)

Fig. 2. XRD analysis of $\mathrm{CBA}$ and $\mathrm{ZBA}$ in various doses (a) and concentration (b) of $\mathrm{NaOH}$ solution.

The oxide composition of CBA and ZBA were obtained from the XRF analysis showed in Table 1. The XRF analysis indicated that the major components of the CBA and ZBA were $\mathrm{SiO}_{2}, \mathrm{Al}_{2} \mathrm{O}_{3}$, and $\mathrm{Fe}_{2} \mathrm{O}_{3}$. 
Table 1. The Composition of CBA and ZBA.

\begin{tabular}{|c|c|c|}
\hline \multirow{2}{*}{ Oxide } & \multicolumn{2}{|c|}{ Amount (\%) } \\
\hline & CBA & $\mathrm{ZBA}$ \\
\hline $\mathrm{SiO}_{2}$ & 49.07 & 29.52 \\
\hline $\mathrm{Al}_{2} \mathrm{O}_{3}$ & 28.48 & 35.92 \\
\hline $\mathrm{Fe}_{2} \mathrm{O}_{3}$ & 6.64 & 4.37 \\
\hline $\mathrm{TiO}_{2}$ & 2.10 & 1.91 \\
\hline $\mathrm{CaO}$ & 1.68 & 1.40 \\
\hline $\mathrm{MgO}$ & 0.471 & 0.711 \\
\hline $\mathrm{K}_{2} \mathrm{O}$ & 0.604 & 0.172 \\
\hline $\mathrm{SO}_{3}$ & 0.523 & 0.172 \\
\hline $\mathrm{Na}_{2} \mathrm{O}$ & 0.354 & 8.94 \\
\hline $\mathrm{P}_{2} \mathrm{O}_{5}$ & 0.103 & 0.0271 \\
\hline LOI & 11.44 & 16.59 \\
\hline
\end{tabular}

The SEM photos showed that CBA had been deformed into ZBA after converting. The difference in Figure 3 showed the amorphous of CBA has a large size between $10 \mu \mathrm{m}-50 \mu \mathrm{m}$ and the ZBA has a more crystalline and small size of about $1 \mu \mathrm{m}$.

Based on the BET analysis, the surface area and pore volume of ZBA has been increased significantly than the CBA as showed in Table 2 . The surface area and pore volume were increased from $0.598 \mathrm{~m}^{2} / \mathrm{g}$ to $60.383 \mathrm{~m}^{2} / \mathrm{g}$ and from $0.013 \mathrm{cc} / \mathrm{g}$ to $0.133 \mathrm{cc} / \mathrm{g}$, respectively. This increase is due to the organic and inorganic pollutants had been removed, so that the closed pores became open. Additionally, the pore radius significantly decreased from $8.91 \mathrm{~nm}$ to 1.53 nm.
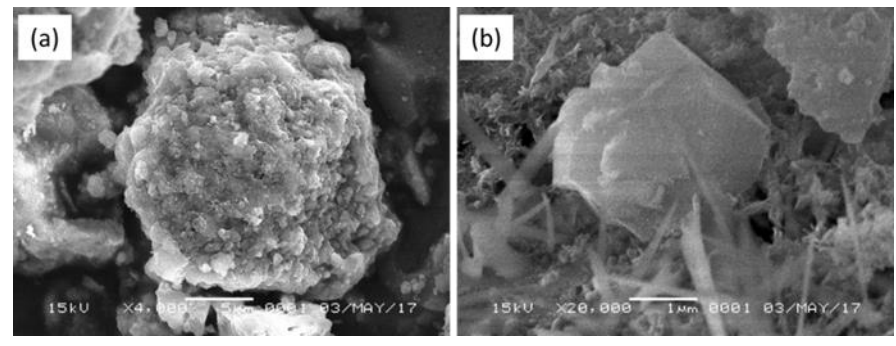

Fig. 3 SEM analysis of CBA (a) and ZBA (b).

Table 2. BET analysis of CBA and ZBA.

\begin{tabular}{ccccccccc}
\hline Material & $\mathrm{S}_{\mathrm{BET}}$ & $\mathrm{V}_{\text {micro }}$ & \multicolumn{2}{c}{$\mathrm{V}_{\text {meso }}(\mathrm{cc} / \mathrm{g})$} & \multicolumn{2}{c}{$\mathrm{S}_{\text {meso }}\left(\mathrm{m}^{2} / \mathrm{g}\right)$} & \multicolumn{2}{c}{ Pore Radius $(\mathrm{nm})$} \\
& $\left(\mathrm{m}^{2} / \mathrm{g}\right)$ & $(\mathrm{cc} / \mathrm{g})$ & Adsorp & Desorp & Adsorp & Desorp & Adsorp & Desorp \\
\hline CBA & 0.598 & 0.016 & 0.013 & 0.009 & 0.721 & 0.925 & 8.91 & 1.89 \\
ZBA & 60.38 & 0.022 & 0.133 & 0.138 & 26.45 & 45.02 & 1.53 & 1.91 \\
\hline
\end{tabular}

\subsection{Adsorption Study}

The adsorption capacities of ZBA were investigated using the batch method Figure 4. The experimental data were plotted and analyzed using Langmuir and Freundlich adsorption isotherm models. Based on the correlation factor, the ammonium ion data adsorption fitted the Freundlich isotherm model as showed in Table 3. Freundlich isotherm suggested a multilayer 
interaction between adsorbent and adsorbate with distribution and adsorption affinity on the heterogeneous surface uniformly. The number of $1 / \mathrm{n}>1$ was confirmed the adsorption mechanism of ammonium ion may involve chemisorption and physisorption (cooperative adsorption) [23].

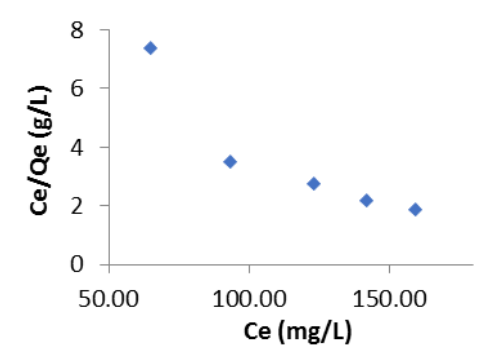

(a) Langmuir isotherm

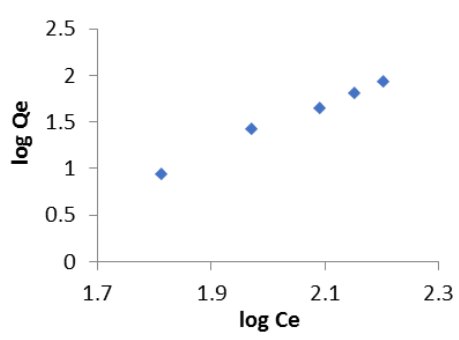

(b) Freundlich isotherm

Fig. 4. Adsorption capacities of ZBA on ammonium ion.

Table 3. Langmuir and Freundlich Isotherm data for ZBA.

\begin{tabular}{ccccccc}
\hline \multirow{2}{*}{ Ion } & \multicolumn{3}{c}{ Langmuir Isotherm } & \multicolumn{3}{c}{ Freundlich Isotherm } \\
\cline { 2 - 6 } & $\mathrm{Q}_{\mathrm{m}}(\mathrm{mg} / \mathrm{g})$ & $\mathrm{K}_{\mathrm{L}}(\mathrm{L} / \mathrm{mg})$ & $\mathrm{R}^{2}$ & $1 / \mathrm{n}$ & $\mathrm{K}_{\mathrm{F}}(\mathrm{mg} / \mathrm{g})$ & $\mathrm{R}^{2}$ \\
\hline $\mathrm{NH}_{4}{ }^{+}$ & 44.3 & 0.0055 & 0.8309 & 2.815 & $2.9 \times 10^{-4}$ & 0.9917 \\
\hline
\end{tabular}

If compared with another zeolite, the maximum adsorption capacity of ZBA is higher than those of Na-P1 zeolite from coal fly ash, sodium-natural zeolite, and natural zeolite. However, the adsorption capacity of ZBA is lower than the zeolite A and zeolite X from coal fly ash. The Comparison of zeolites showed in Table 4.

Table 4. The comparison of zeolites.

\begin{tabular}{cccc}
\hline Zeolites & Based & $\left.\mathbf{Q}_{\mathbf{m}} \mathbf{( m g} / \mathbf{g}\right)$ & Sources \\
\hline Zeolite X & Coal fly ash & 139 & \\
\hline Zeolite A & Coal bottom ash & 66.667 & This study \\
Zeolite ZBA & Coal bottom ash & 44.3 & \\
Zeolite Na-P1 & Coal fly ash & 16.36 & \\
Sodium-Natural zeolite & Natural Zeolite & 11.18 & \\
Natural Zeolite & - & $4.4-4.5$ & \\
\hline
\end{tabular}

\subsection{Desorption Study}

The desorption of ammonium ion from ZBA was studied using the column method Figure 5. For the first $3 \mathrm{~h}$, the desorption process occurred rapidly and the ammonium ions must be decreased in a large number. The nitrogen in the ammonium was leached about $2.5 \mathrm{ppm} / \mathrm{h}$. Then after $4 \mathrm{~h}$ up to $30 \mathrm{~h}$ and the next $71 \mathrm{~h}$, the ammonium ions were released from ZBA about 0.32 ppm and $0.15 \mathrm{ppm}$, respectively. That result was appropriated with the adsorption mechanism, 
the high desorption during the initial 3 hours was indicated the physisorption and for the next hours was indicated the chemisorption mechanism.

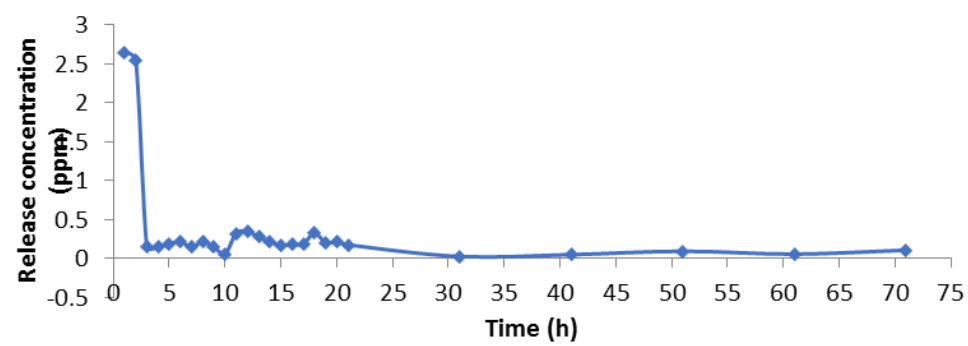

Fig. 5. Desorption process of ZBA on ammonium ion.

\section{Conclusion}

Zeolite has been synthesized from CBA using $\mathrm{NaOH}$ at $90^{\circ} \mathrm{C}$ for $24 \mathrm{~h}$. FTIR analysis indicated the absorbance peak of zeolite at $559.3 \mathrm{~cm}^{-1}$. The zeolite synthetic has a formula $1.05 \mathrm{Na}_{2} \mathrm{O} . \mathrm{Al}_{2} \mathrm{O}_{3} .3 .8 \mathrm{SiO}_{2} .4 .7 \mathrm{H}_{2} \mathrm{O}$ that confirmed by XRD analysis. BET analysis showed that the surface area of CBA was $0.598 \mathrm{~m}^{2} / \mathrm{g}$, while that for ZBA was $60.383 \mathrm{~m}^{2} / \mathrm{g}$, respectively. The maximum adsorption capacities $\left(\mathrm{Q}_{\mathrm{m}}\right)$ of zeolite (ZBA) on ammonium ion was $85.22 \mathrm{mg} / \mathrm{g}$. When fitted using Langmuir and Freundlich isotherm models, the ammonium ion adsorption data fitted Freundlich isotherm. It was suggested that the interaction between zeolite and ammonium ion leads to physisorption and chemisorption in a multilayer interaction. The desorption process of ammonium ion was occurred rapidly for the first $3 \mathrm{~h}$ and slowly for the next hours.

\section{References}

[1] C. Li, Y. Dong, Y. Lei, D. Wu, and P. Xu.: "Removal of low concentration nutrients in hydroponic wetlands integrated with zeolite and calcium silicate hydrate functional substrates," Ecol. Eng., no. 82, pp. 442-450 (2015)

[2] H. Huang, X. Xiao, B. Yan, and L. Yang.: "Ammonium removal from aqueous solutions by using natural Chinese (Chende) zeolite as adsorbent," J. Hazard. Mater., vol. 175, no. 1-3, pp. 247-25 (2010) [3] M. Zhang et al.: "Ammonium removal from aqueous solution by zeolites synthesized from lowcalcium and high-calcium fl y ashes," DES, vol. 277, no. 1-3, pp. 46-53 (2011)

[4] Y. Zhao et al.: "Removal of ammonium ions from aqueous solutions using zeolite synthesized from red mud," Desalin. Water Treat., vol. 57, no. 10, pp. 4720-471 (2016)

[5] J. Huang, N. R. Kankanamge, C. Chow, D. T. Welsh, T. Li, and P. R. Teasdale.: "Removing ammonium from water and wastewater using cost-effective adsorbents: A review," J. Environ. Sci. 63, pp. 174-197 (2018)

[6] K. Pimraksa, P. Chindaprasirt, T. Huanjit, C. Tang, and T. Sato.: "Cement mortars hybridized with zeolite and zeolite-like materials made of lignite bottom ash for heavy metal encapsulation," J. Clean. Prod., vol. 41, pp. 31-41 (2013) 
[7] N. Widiastuti, M. Zhely, N. Hidayah, D. Praseytoko, and H. Fansuri.: "Synthesis of zeolite X-carbon from coal bottom ash for hydrogen storage material," Adv. Mater. Lett., vol. 5, no. 8, pp. 453-458 (2014)

[8] N. A. Rashidi and S. Yusup.: "An Overview on the Potential of Coal-Based Bottom Ash as LowCost Adsorbents.: " ACS Sustinable Chem. Eng., vol. 4, no. 4, pp. 1870-1884, 2016.

[9] H. Sukpreabprom, O.-A. Arquero, W. Naksata, P. Sooksamiti, and S. Janhom.: "Isotherm, Kinetic and Thermodynamic Studies on the Adsorption of Cd (II) and Zn (II) ions from Aqueous Solutions onto Bottom Ash," Int. J. Environ. Sci. Dev., vol. 5, no. 2, pp. 165-170 (2014)

[10] M. Singh and R. Siddique.: "Effect of coal bottom ash as partial replacement of sand on properties of concrete," Resour. Conserv. Recycl., vol. 72, pp. 20-32 (2013)

[11] H. K. Kim and H. K. Lee, "Coal Bottom Ash in Field of Civil Engineering.: A Review of Advanced Applications and Environmental Considerations," KSCE J. Civ. Eng., vol. 19, no. 6, pp. 1802-1818 (2015)

[12] A. C. M. Loy et al.: "The effect of industrial waste coal bottom ash as catalyst in catalytic pyrolysis of rice husk for syngas production," Energy Convers. Manag., vol. 165, pp. 541-554 (2018)

[13] H. Wang, X. Wang, Z. Xu, and M. Zhang.: "Synthetic zeolite from coal bottom ash and its application in cadmium and nickel removal from acidic wastewater," Desalin. Water Treat., vol. 3994, no. March, pp. 1-12 ( 2016)

[14] Y. Zhao, B. Zhang, X. Zhang, J. Wang, J. Liu, and R. Chen.: "Preparation of highly ordered cubic $\mathrm{NaA}$ zeolite from halloysite mineral for adsorption of ammonium ions," J. Hazard. Mater., vol. 178, no. 1-3, pp. 658-664 (2010)

[15] H. Huang, L. Yang, Q. Xue, J. Liu, L. Hou, and L. Ding.: "Removal of ammonium from swine wastewater by zeolite combined with chlorination for regeneration," J. Environ. Manage., pp. 1-9 ( 2015)

[16] A. Setiabudi, N. Nashrah, H. P. Putri, and G. Yuliani.: "Adsorptive Properties of Fly Ash Zeolite Synthesized via Microwave and Ultrasonic Pretreatments," vol. 751, pp. 751-755 (2017)

[17] G. T. M. Kadja, R. R. Mukti, and I. N. Marsih.: "A Comparative Study of the Synthesis of MFI Zeolite by Using High- and Low-Temperature Heating,” vol. 1112, pp. 201-204 (2015) 